\title{
Molecular characterization of nocardioform actinomycetes in activated sludge by 165 rRNA analysis
}

\author{
Markus Schuppler, ${ }^{1}$ Frank Mertens, ${ }^{2}$ Georg Schön ${ }^{2}$ and UIf B. Göbel ${ }^{1} \dagger$
}

Author for correspondence: Ulf B. Göbel. Tel: +4930609 3247. Fax: +49302292741.

1 Institut für Medizinische Mikrobiologie und Hygiene, Klinikum der Albert-Ludwigs-Universităt Freiburg, Hermann-HerderStraße 11, D-79104

Freiburg, Germany

2 Institut für Biologiell/Mikrobiologie, Albert-Ludwigs-Universităt Freiburg, Schănzlestraße 1, D-79104 Freiburg, Germany
The analysis of complex microbiota present in activated sludge is important for the understanding and possible control of severe separation problems in sewage treatment such as sludge bulking or sludge foaming. Previous studies have shown that nocardioform actinomycetes are responsible for these conditions, which not only affect the efficiency of sewage treatment but also represent a threat to public health due to spread of pathogens. However, isolation and identification of these filamentous, nocardioform actinomycetes is hampered by their fastidious nature. Most species are still uncultivable and their taxonomy is unresolved. To study the ecology of these micro-organisms at the molecular level, we have established a clone library of 16S rRNA gene fragments amplified from bulk sludge DNA. A rough indication of the predominant flora in the sludge was given by sequencing randomly chosen clones, which revealed a great diversity of bacteria from different taxa. Colony hybridization with oligonucleotide probe MNP1 detected 27 clones with 165 rDNA inserts from nocardioform actinomycetes and mycobacteria. The sequence data from these clones together with those from randomly chosen clones were used for comparative 165 rRNA analysis and construction of dendrograms. All sequences differed from those of previously sequenced species in the databases. Phenotypic characterization of isolates of nocardioform actinomycetes and mycobacteria cultivated in parallel from the same activated-sludge sample revealed a large discrepancy between the two approaches. Only one 165 rDNA sequence of a cultured isolate was represented in the clone library, indicating that culture conditions could select species which represent only a small fraction of the organisms in the activated sludge.

Keywords: 16 S rRNA, activated sludge, nocardioform actinomycetes, uncultured bacteria

\section{INTRODUCTION}

The performance of a sewage treatment plant depends upon the microbial community of the activated sludge. Domestic sewage contains a large number of microorganisms that play a major role in the biodegradation of

\footnotetext{
†Present address: Medizinische Fakultăt (Charité), Humboldt-Universităt Berlin, Institut für Mikrobiologie und Hygiene, Clara Zetkin Str. 96, D-10117 Berlin.

Abbreviation: EBPR, enhanced biological phosphorus removal.

The EMBL, GenBank and DDBJ accession numbers for the 37 nucleotide sequences from the $16 \mathrm{~S}$ rDNA clone library reported in this paper are $X 78629$ to $X 78665$.
}

organic matter, the removal of inorganic compounds, the inactivation of human or animal pathogens, and the detoxification of pollutants. The composition of activated sludge flocs, consisting of clusters of filamentous and unicellular bacteria, determines the biodegradation efficiency and proper settling in the secondary clarifier. Growth imbalance of filamentous vs floc-forming bacteria leads to problems known as sludge bulking and sludge foaming. The latter condition not only reduces the efficiency of sewage treatment, but also represents a public health problem, due to the spread of pathogens in windblown scum (Blackall et al., 1988), and the contamination of the receiving water with opportunistic pathogens, including mycobacteria or nocardioform actinomycetes such as Rhodococcus equi, Nocardia asteroides or Gordona 
Table 1. Reference strains and results of identification by gas chromatography

\begin{tabular}{|c|c|c|c|}
\hline Reference strains & Source* & GC-identification & $\begin{array}{c}\text { Probability } \\
(\%)\end{array}$ \\
\hline Corynebacterium variabilis & DSM 20536 & No valid result & - \\
\hline Gordona aurantiaca $\dagger$ & DSM 43246 & No valid result & - \\
\hline Gordona rubropertinctus & DSM 43197 & $\begin{array}{l}\text { Nocardia otitidiscaviarum/ } \\
\text { G. rubropertinctus }\end{array}$ & $62 / 41$ \\
\hline Gordona rubropertinctus & DSM 43248 & Gordona rubropertinctus & 65 \\
\hline Gordona terrae & DSM 43249 & $\begin{array}{l}\text { Gordona rubropertinctus/ } \\
\text { Gordona terrae }\end{array}$ & $66 / 55$ \\
\hline Nocardia amarae & DSM 43392 & Nocardia amarae & 65 \\
\hline Rbodococcus equi & ITH & Not determined & - \\
\hline Rhodococcus erythropolis & DSM 43066 & Rbodococcus erythropolis & 60 \\
\hline Rhodococcus erythropolis & DSM 43135 & Rbodococcus erythropolis & 41 \\
\hline Rbodococcus fascians & DSM 20669 & Rhodococcus fascians & 65 \\
\hline Rbodococcus rbodochrous & DSM 43241 & Rbodococcus rbodochrous & 62 \\
\hline Rhodococcus ruber & DSM 43338 & Rbodococcus rbodocbrous & 75 \\
\hline Rbodococcus sp. & DSM 427 & No valid result & - \\
\hline
\end{tabular}

*DSM, Deutsche Stammsammlung für Mikroorganismen, Braunschweig, Germany; ITH, Institut für Tierhygiene, Freiburg, Germany.

† Renamed Tsukamurella paurometabola.

broncbialis (Lasker et al., 1992). Several studies indicated that sludge foaming is often caused by an increase in the amount of nocardioform actinomycetes (Lemmer \& Kroppenstedt, 1984; Sezgin et al., 1988; Wanner \& Grau, 1989). Since nocardioform actinomycetes and other Gram-positive bacteria with high $\mathrm{G}+\mathrm{C}$ content occur preferentially in sewage treatment plants with enhanced biological phosphorus removal (EBPR) (Wagner et al., 1994), plants of this type are especially susceptible to developing scum. Increasing eutrophication of natural waters is resulting in tougher wastewater legislation and an increasing number of EBPR plants. Thus, scum in wastewater treatment plants is likely to remain a problem in future. A thorough microbial analysis of activated sludge is therefore a prerequisite for the understanding and possible control of the sewage process and the problems which can arise.

Until recently, the analysis of natural microbial communities such as those in activated sludge relied on the cultivation of the resident micro-organisms as a prerequisite for subsequent identification. This classical approach, however, is hampered by the lack of information on appropriate culture conditions for many of the micro-organisms. Earlier studies indicate that only about $10 \%$ of a population is cultivable (Jones, 1977; Hoppe, 1978; Ferguson et al., 1984; Atlas, 1983; Pickup, 1991). Recently, comparative sequence analysis of ribosomal RNA has been widely accepted as a tool for the identification and phylogenetic classification of bacteria (Woese et al., 1985; Olsen et al., 1986; Woese, 1987; Winker \& Woese, 1991; Fox et al., 1992). The great advantage of rRNA analysis and rRNA-based hybridization probes in microbial ecology is that the microorganisms present in a natural community can be detected and characterized without prior cultivation (Göbel et al.,
1987; Giovannoni et al., 1988; DeLong et al., 1989; Amann et al., 1990; Hahn et al., 1992; Spring et al., 1992).

Comparative 16S rRNA sequence analysis has been applied to studies of natural microbial communities and has resulted in the discovery of unexpectedly high levels of biodiversity (Pace et al., 1986; Weller \& Ward, 1989; Giovannoni et al., 1990; Amann et al., 1991; Schmidt et al., 1991; Fuhrman et al., 1992).

In this study we investigated the microbial diversity of an activated-sludge sample from a sewage treatment plant, with particular regard to nocardioform actinomycetes and mycobacteria, by comparative $16 \mathrm{~S}$ rRNA sequence analysis. A library of in vitro-amplified 16S rRNA genes of activated-sludge bacteria was screened with an oligonucleotide probe in order to detect clones with $16 \mathrm{~S}$ rDNA signature sequences of nocardioform actinomycetes and mycobacteria, and positive clones were sequenced and analysed. In parallel we isolated actinomycetes from the same activated-sludge sample and compared the partial $16 \mathrm{~S}$ rRNA sequences of these cultured isolates with those obtained from the clone library.

\section{METHODS}

Micro-organisms. An activated-sludge sample was taken from a normally functioning municipal wastewater treatment plant with EBPR at Berlin-Marienfelde, Germany, in October 1992. Isolation of nocardioform actinomycetes was achieved by directly streaking the undiluted sludge onto agar plates with modified Czapek Dox medium (Difco) which is selective for actinomycetes (Lechevalier, 1989). After incubation at $20^{\circ} \mathrm{C}$ for one week, colonies were picked at random, transferred to TSBA (trypticase soy broth) agar plates (BBL) and incubated for $2 \mathrm{~d}$ at $30^{\circ} \mathrm{C}$. Isolates were identified by gas chromatography (Miller, 1982) on a Hewlett-Packard HP5890 series II using the MIS 
Table 2. Comparison of identification of culture isolates by gas chromatography and 165 rRNA sequence analysis

\begin{tabular}{|llclc|}
\hline Isolate & GC-identification & $\begin{array}{c}\text { Probability } \\
\text { (\%) }\end{array}$ & 16S rRNA sequence analysis* & $\begin{array}{c}\text { Similarity } \\
\text { (\%) }\end{array}$ \\
\hline M2 & Nocardia amarae & 34 & Mycobacterium fallax & $88 \cdot 4$ \\
M3 & Nocardia amarae & 41 & Mycobacterium fallax & $90 \cdot 7$ \\
M7 & Rhodococcus chubuensis & 50 & Mycobacterium fallax & $93 \cdot 9$ \\
M8 & Rbodococcus chubuensis & 61 & Mycobacterium fallax & $93 \cdot 9$ \\
M12 & Rhodococcus globerulus & 76 & Mycobacterium chlorophenolicum & $91 \cdot 6$ \\
M24 & Gordona rubropertinctus & 59 & Mycobacterium fallax & $93 \cdot 9$ \\
M26 & No valid result & - & Mycobacterium farcinogenes & $85 \cdot 3$ \\
M28 & Rhodococcus rbodochrous & 54 & Mycobacterium fallax & $88 \cdot 6$ \\
M34 & Gordona rubropertinctus & 69 & Mycobacterium fallax & $93 \cdot 9$ \\
M49 & Rbodococcus globerulus & 63 & Mycobacterium chloropbenolicum & $93 \cdot 1$ \\
\hline
\end{tabular}

* Closest relationship to $16 \mathrm{~S}$ rRNA sequences from EMBL or GenBank databases.

software. Reference strains included in this study are listed in Table 1.

Nucleic acid preparation. Part of the same activated-sludge sample which was used for isolation of the nocardioform actinomycetes was processed for nucleic acid preparation. The sample was centrifuged, washed twice in an excess of PBS ( $\mathrm{pH} 7 \cdot 0)$, and finally resuspended in PBS. DNA was recovered by adding $0.5 \mathrm{ml}$ of the sample to approximately $0.5 \mathrm{ml}$ zirconium beads $(0.1 \mathrm{~mm}$ diameter $)$ and $0.5 \mathrm{ml}$ phenol. Bacteria were then mechanically disrupted by shaking the tube for $5 \mathrm{~min}$ in a MiniBead Beater (Biospec Products, Bartlesville, USA) at room temperature. After phase separation $(10 \mathrm{~min}$ at $15000 \mathrm{~g})$, the aqueous phase was extracted twice by adding 1 vol. phenol/ chloroform $(1: 1, \mathrm{v} / \mathrm{v})$ and $1 \mathrm{vol}$. chloroform/isoamyl alcohol $(24: 1, \mathrm{v} / \mathrm{v})$. DNA was precipitated by adding 2 vols ice-cold ethanol $(96 \%)$. The pellet was dried under vacuum for $10 \mathrm{~min}$, dissolved in $50 \mu \mathrm{TE}$ buffer $(10 \mathrm{mM}$ Tris/ $\mathrm{HCl}, \mathrm{pH} 8.0,1 \mathrm{mM}$ EDTA) and purified twice on StrataClean resin (Stratagene).

PCR amplification. PCR was used to amplify 16S rRNA gene fragments from purified genomic DNA of the culture isolates as well as from the purified genomic DNA of the activated-sludge sample. The PCR mixture contained $1 \times$ PCR buffer $[50 \mathrm{mM}$ $\mathrm{KCl}, 1.5 \mathrm{mM} \mathrm{MgCl}, 10 \mathrm{mM}$ Tris $/ \mathrm{HCl}$ (pH 9.0), $10 \mu \mathrm{g}$ gelatin $\mathrm{ml}^{-1}$ ], $200 \mu \mathrm{M}$ dNTPs, $0.3 \mu \mathrm{M}$ each of primers RETPU1 [5'-CCG AAT TCG TCG ACA ACA GAG TTT GAT CCT GGC 'TCA G-3'; corresponding to positions 8-27 in E. coli 16S rRNA (Brosius et al., 1978); the underlined sequence represents restriction sites for EcoRI and $S a l l]$ and RE-RTU3 [5'-CCC GGG ATC CAA GCT TG(T/A) ATT ACC GCG GC(G/T) GCT G-3'; corresponding to complementary positions 519-536 in E. coli 16S rRNA (Brosius et al., 1978); the underlined sequence at the $5^{\prime}$-end represents restriction sites for Bam HI, HindIII and SmaI], 1.5 U Taq polymerase (Gibco BRL) and approximately 10-100 ng DNA in a final reaction volume of $100 \mu \mathrm{l}$. Amplification was performed in an automated thermal cycler (model 480, Perkin-Elmer-Cetus) by denaturing the samples at $95^{\circ} \mathrm{C}$ for $2 \mathrm{~min}$ and subsequent amplification by 30 cycles of denaturing $\left(92^{\circ} \mathrm{C}\right.$ for $\left.1 \mathrm{~min}\right)$, annealing $\left(50^{\circ} \mathrm{C}\right.$ for $1 \mathrm{~min}$ ) and elongation $\left(72^{\circ} \mathrm{C}\right.$ for $\left.1.5 \mathrm{~min}\right)$. Amplification products were purified by agarose gel electrophoresis, eluted by centrifugation using small Mobicol columns (Mobitech), then precipitated with ethanol and resuspended in TE buffer. 16S rRNA gene fragments of culture isolates and type strains were amplified as described above, with the exception of using primers TPU1 and RTU3 without polylinker tails. Direct solidphase sequencing PCR was performed using biotinylated primers TPU1 or RTU3.

Cloning. Purified 16S rDNA PCR products and plasmid vector pUC19 (Pharmacia) were cleaved by a double digest with restriction endonucleases $S_{a} I$ and $B a m H I$ (Pharmacia) following the manufacturer's specifications. Cleaved products were purified twice on a StrataClean resin. Three ligation reactions using 50,100 or $200 \mathrm{ng}$ of vector pUC19 were performed. Each reaction contained $6 \mu \mathrm{l}$ restriction-enzyme-digested PCR product, $1 \mathrm{U}$ T4 DNA ligase (BRL) and $25 \mathrm{mM}$ Tris/ $\mathrm{HCl}$ buffer (pH 7.8) containing $10 \mathrm{mM} \mathrm{MgCl}, 1 \mathrm{mM} \mathrm{DTT}$ and $1 \mathrm{mM}$ ATP, in a final volume of $10 \mu \mathrm{l}$. The ligation reactions were incubated at $16^{\circ} \mathrm{C}$ overnight. Transformation was done by adding $5 \mu$ l ligation mix to $100 \mu$ l competent E. coli SURE cells (Stratagene) according to the manufacturer's recommendation. Aliquots $(100 \mu \mathrm{l})$ of the cell suspension were plated onto LB agar medium (Gibco) containing $100 \mu \mathrm{g}$ ampicillin $\mathrm{ml}^{-1}$, $0.004 \%(w / v)$ of X-Gal (Boehringer Mannheim) and $0.5 \mathrm{mM}$ of IPTG (BRL) and incubated overnight at $37^{\circ} \mathrm{C}$.

Colony hybridization. Recombinant clones were plated onto LB agar supplemented with $0.1 \mathrm{mg}$ ampicillin $\mathrm{ml}^{-1}$. The resulting colonies were transferred to positively charged Biodyne B nylon membranes (Pall). The bacterial colonies were lysed by standard methods (Sambrook et al., 1989). The oligonucleotide probe MNP1 recognizing the target sequence 5'-AGC CTG GGA AAC TGG GTC TAA-3' [corresponding to positions 152-172 in E. coli 16S rRNA (Brosius et al., 1978)] was labelled at the $5^{\prime}$-end with $\left[\gamma_{-}{ }^{32} \mathrm{P}\right]$ ATP $\left(5 \mathrm{kCi} \mathrm{mmol}^{-1}\right.$, $185 \mathrm{TBq} \mathrm{mmol}^{-1}$; Amersham) using $\mathrm{T} 4$ polynucleotide kinase (BRL). Hybridizations were carried out in glass tubes. Filters were prehybridized at $52^{\circ} \mathrm{C}$ for $1 \mathrm{~h}$ using $20 \mathrm{ml}$ hybridization buffer $[5 \times$ SSC, $5 \times$ Denhardt's reagent $(50 \times$ Denhardt's reagent contains $5 \mathrm{~g}$ Ficoll, $5 \mathrm{~g}$ polyvinylpyrrolidone, $5 \mathrm{~g}$ BSA and $\mathrm{H}_{2} \mathrm{O}$ to $500 \mathrm{ml}$ ), $0.5 \%$ (w/v) SDS] and $2 \mathrm{ml}$ sheared herring sperm DNA $\left(10 \mathrm{mg} \mathrm{ml}^{-1}\right)$. For the subsequent hybridization $\left(1 \mathrm{~h}\right.$ at $\left.52^{\circ} \mathrm{C}\right) 20 \mathrm{ml}$ hybridization buffer, $200 \mu \mathrm{l}$ tRNA ( $25 \mathrm{mg} \mathrm{ml}^{-1}$ ) and labelled probe MNP1 (about $2.5 \times 10^{6}$ c.p.m.) were added. After hybridization the membranes were washed at low stringency $\left(54^{\circ} \mathrm{C}\right.$ for $3 \mathrm{~min}$ ) and then at a slightly higher stringency $\left(56^{\circ} \mathrm{C}\right.$ for $\left.5 \mathrm{~min}\right)$ using washing buffer $(5 \times \mathrm{SSC}$, $0.2 \%$ SDS).

165 rDNA sequencing. Plasmid DNA was purified using the QIAprep-spin Plasmid Kit (QIAGEN) as indicated by the 


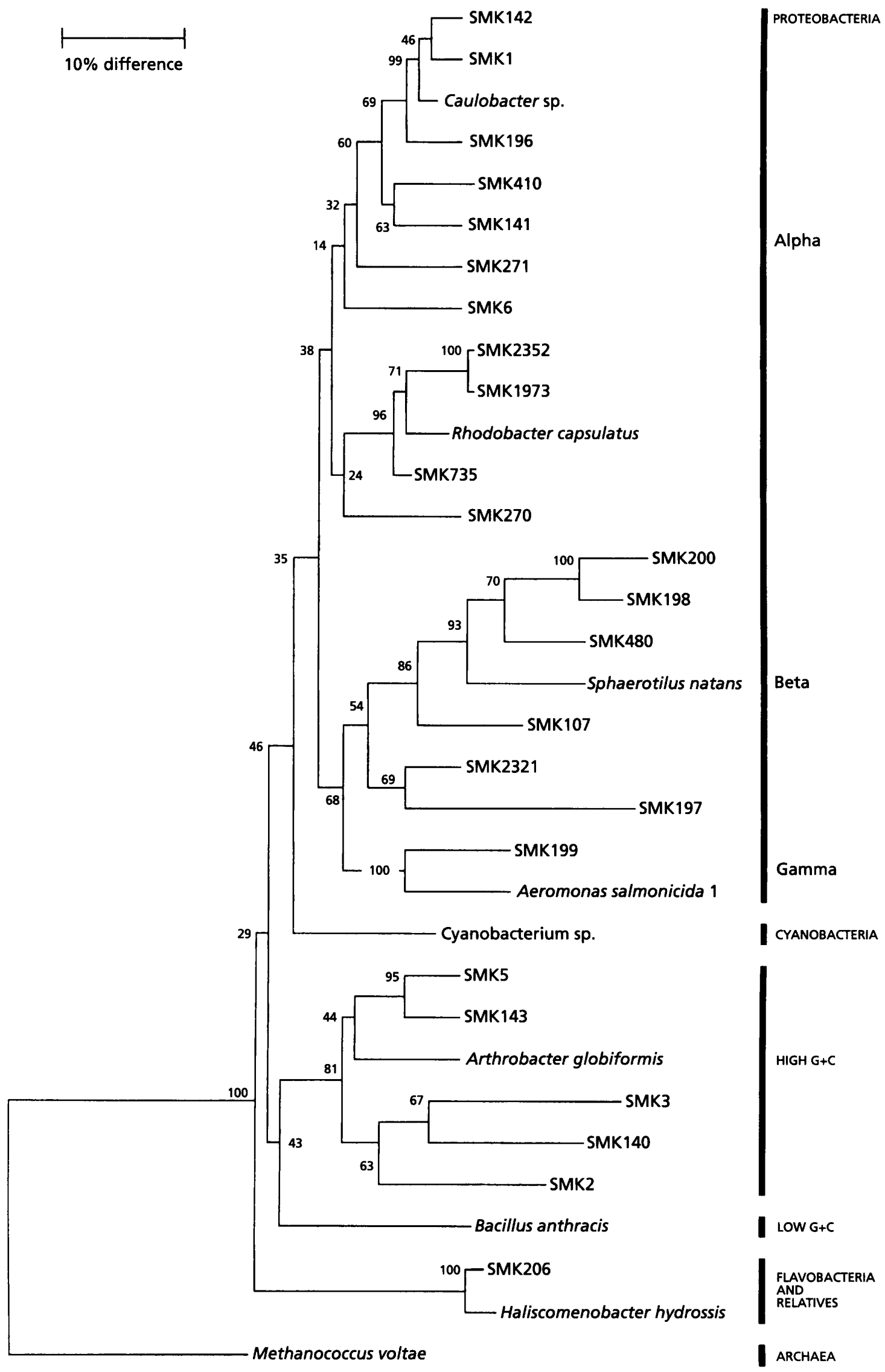

Fig. 1. For legend see facing page. 
manufacturer. Both insert strands were sequenced by a modified Sanger dideoxy chain-termination protocol using Sequenase (USB) according to the manufacturer's instructions. Biotinylated PCR products were directly sequenced by a solidphase single-strand sequencing method. Briefly, biotinylated PCR products were incubated with streptavidin-coated paramagnetic beads (Dynabeads, Dynal) and strands were separated by addition of $8 \mu \mathrm{l} 0.5 \mathrm{M} \mathrm{NaOH}$. The tube was placed in a magnetic rack and the supernatant, containing the unbiotinylated strand, was removed. Purified, biotinylated single strands were sequenced using Sequenase, following the manufacturer's recommendations. Primers TPU1 and RTU3 without polylinker tails were used as forward and reverse primers, respectively.

$16 S$ rRNA sequence analysis. The $16 \mathrm{~S}$ rDNA sequences were compared with all currently accessible (June 1994) 16S rRNA sequences in the EMBL and GenBank databases using the program FASTA of the HUSAR 3.0 (Heidelberg Unix Sequence Analysis Resources) program package (DKFZ, Heidelberg, Germany). The clone sequences were aligned with a set of published sequences of several reference bacteria on the basis of conserved primary sequence. The TREECON software package for construction and drawing of evolutionary trees was used for sequence analysis and construction of the dendrograms (Van de Peer \& De Wachter, 1993). A 'Single Distance Matrix' was calculated from the first 500 bases of the $16 \mathrm{~S}$ rRNAs including hypervariable regions, and corrected for superimposed mutations by the method of Jukes \& Cantor (1969). The neighbour-joining method of Saitou \& Nei (1987) was used for phylogenetic tree construction. The reliability of tree nodes was analysed by bootstrapping. One hundred bootstrap trees were generated, and confidence levels were determined.

\section{RESULTS}

\section{Characterization of culture isolates}

About 50 culture isolates grown from the activatedsludge sample on Czapek Dox agar were identified by gas chromatography. Isolates showing identical fatty acid profiles were classified in the same group. The $16 \mathrm{~S} \mathrm{rDNA}$ of one representative strain from each of these groups was partially sequenced. GC-identification and 16S rRNA analysis resulted in a different classification of the isolates and showed a high degree of discrepancy between the two approaches (Table 2).

\section{5 rDNA clone library of activated sludge bacteria}

Bulk DNA extracted from the activated-sludge sample was used as a mixed template for PCR-amplification of the first 500 bases, representing approximately one-third of the whole 16S rRNA gene. Cloning of the PCR products resulted in a $16 \mathrm{~S}$ rDNA clone library. The cloning efficiency was $2.14 \times 10^{5}$ c.f.u. per $\mu \mathrm{g}$ vector DNA for the ligation reaction with $100 \mathrm{ng}$ pUC19 DNA. About 3000 recombinant clones were randomly selected and transferred onto LB plates for further investigations.

\section{Colony hybridization with probe MNP1}

Partial 16S rDNA sequences (each about 500 bp) obtained by direct sequencing of PCR products from 13 nocardioform strains (Table 1) and 10 culture isolates (Table 2) were aligned. A sequence motif common to all $16 \mathrm{~S}$ rDNA sequences from these strains and isolates was selected for the construction of oligonucleotide probe MNP1. A search in the EMBL and GenBank databases confirmed that this sequence was found within $16 \mathrm{~S}$ rRNA genes of most members of the genera Corynebacterium, Gordona, Mycobacterium, Nocardia and Rhodococcus and also within a few members of other genera of the high $-\mathrm{G}+\mathrm{C}$ group of Gram-positive bacteria. The $16 \mathrm{~S}$ rRNA sequences of $M$. celatum, M. leprae, $M$. komossense, $M$. shimoidei, R. fascians and Tsukamurella paurometabola showed one mismatch with probe MNP1. To identify the clones containing $16 \mathrm{~S}$ rDNA inserts from nocardioform actinomycetes and mycobacteria, all recombinants of the gene library were screened by colony hybridization with radiolabelled probe MNP1. By using high-stringency conditions 27 out of 3000 clones were identified, all of which contained the full target sequence as determined by sequencing of the plasmid inserts.

\section{Sequence analysis of the clone library}

The composition of the $16 \mathrm{~S}$ rDNA clone library from activated sludge was estimated by sequencing 24 randomly selected recombinant clones. Comparative sequence analysis of the resulting $16 \mathrm{~S}$ rDNA sequences revealed a range of identities from Gram-positive and Gram-negative bacteria. None of the clone sequences showed identity with any of the 16S rRNA sequences found within EMBL or GenBank databases. The phylogenetic relationship of the bacteria represented in the clone library is represented in Fig. 1, which shows that most of the sequences were related to $16 \mathrm{~S}$ rRNA sequences from members of the class Proteobacteria.

Sequence analysis of the 27 MNP1-positive clones resulted in the identification of 13 different $16 \mathrm{~S}$ rDNA sequences. Several clones contained identical sequences, whereas others showed slight differences. About $400 \mathrm{bp}$ of both strands at the $5^{\prime}$-end of $16 \mathrm{~S}$ rRNA genes were sequenced. Comparative sequence analysis with rRNA sequences from the EMBL and GenBank databases revealed that all the sequences could be related to the group of nocardioform actinomycetes and mycobacteria (Fig. 2), with the exception of one sequence (SMKN1), which represented a high- $G+C$ Gram-positive bacterium not belonging to that group. None of the sequences showed $100 \%$ identity with any of the sequences retrieved from databases. However, one clone sequence (SMKN35) was identical to that of an isolate (M49) grown in pure culture from the activated-sludge sample. Sequence SMKN41

Fig. 1. Dendrogram indicating the phylogenetic relationships among selected bacteria representing different phylogenetic taxa and randomly chosen clones (SMK). The dendrogram is rooted by outgroup Methanococcus voltae. The scale bar represents $10 \%$ difference in nucleotide sequence determined by taking the sum of the length of the horizontal line segments connecting two organisms. Numbers above each node are confidence levels (\%) generated from 100 bootstrap trees (Van de Peer \& De Wachter, 1993). 

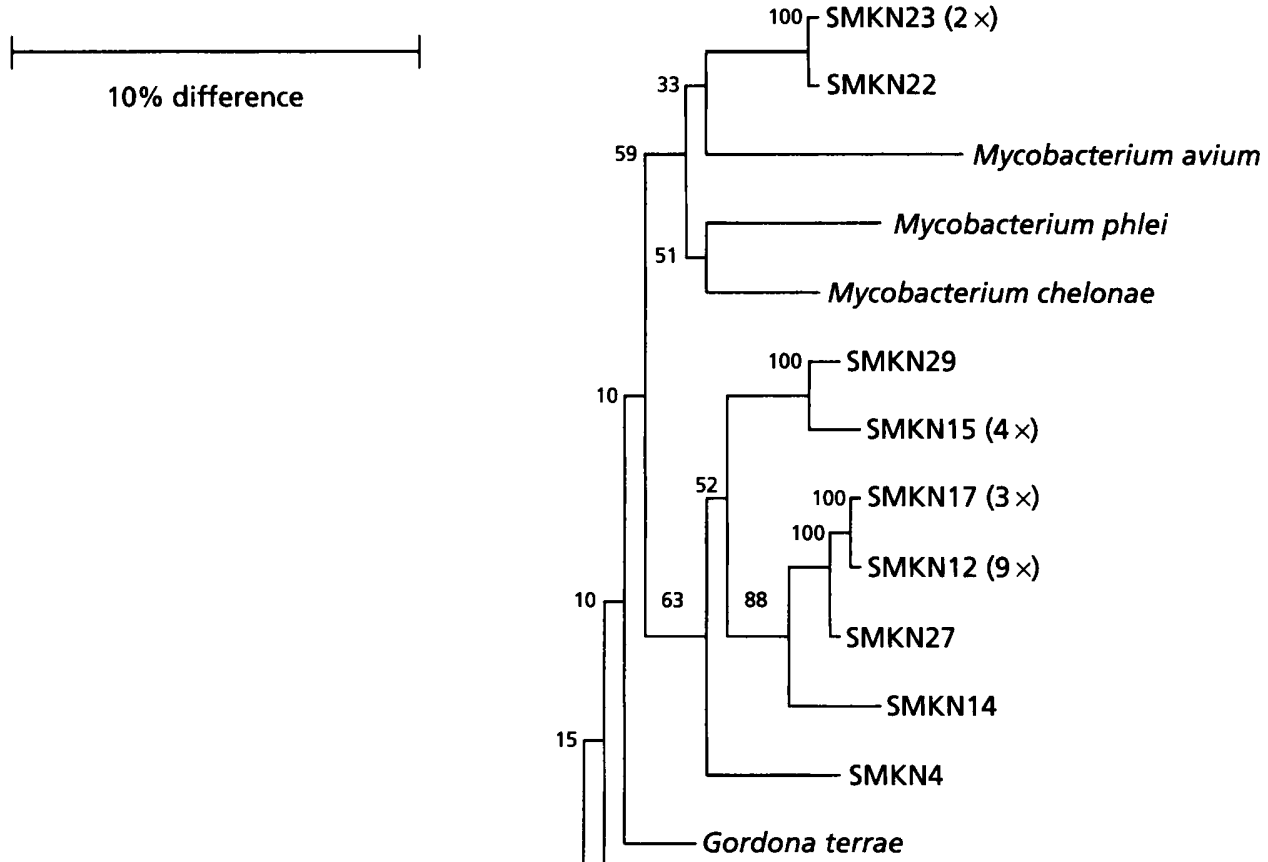

Tsukamurella paurometabola

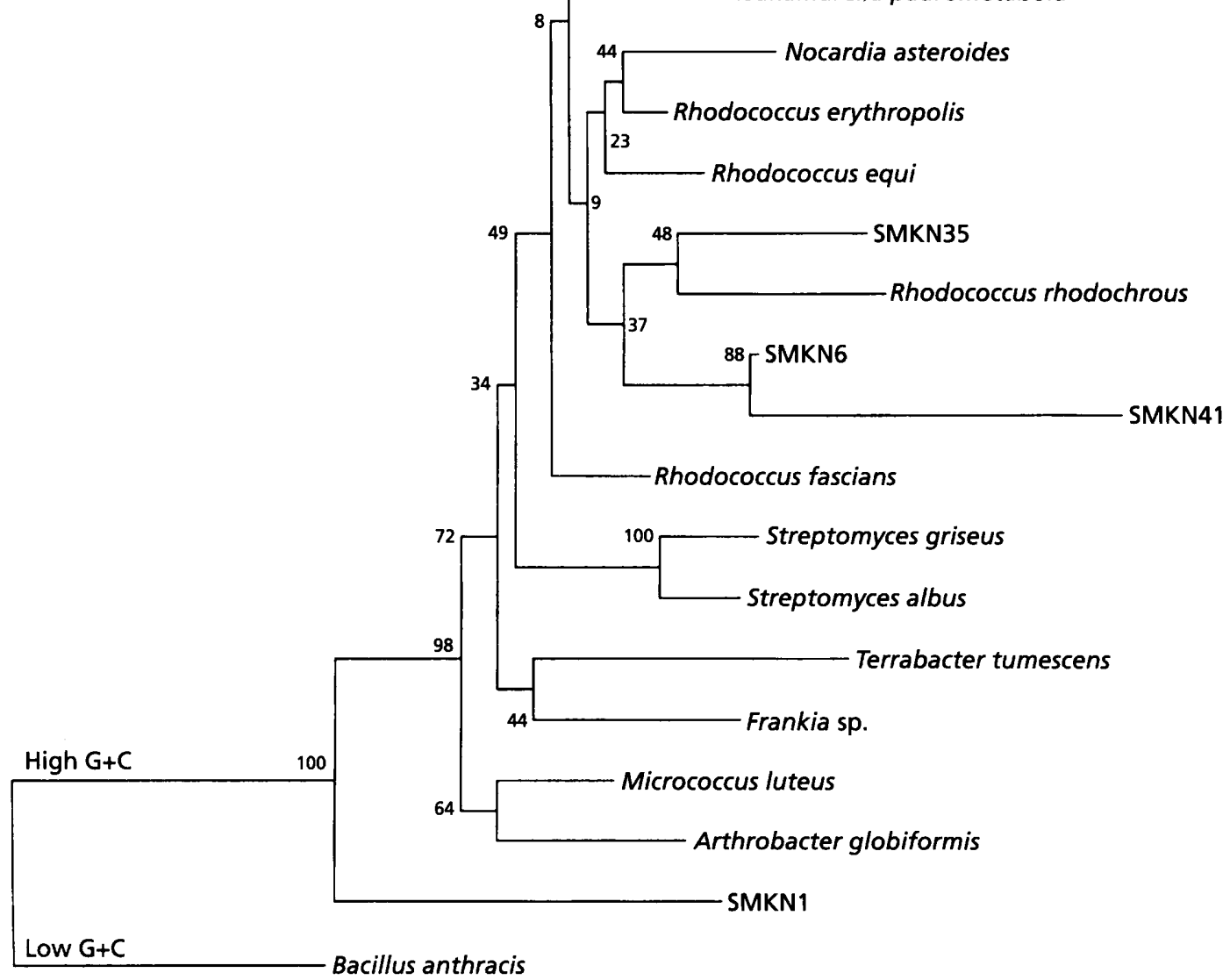

Fig. 2. Dendrogram indicating the phylogenetic relationships among selected Gram-positive bacteria and clones (SMKN) identified by probe MNP1. One representative from each group of identical clone sequences is shown (numbers in brackets indicate the number of identical sequences). The dendrogram is rooted by outgroup Bacillus anthracis. The scale bar represents $10 \%$ difference in nucleotide sequence determined by taking the sum of the length of the horizontal line segments connecting two organisms. The numbers above each node are confidence levels (\%) generated from 100 bootstrap trees (Van de Peer \& De Wachter, 1993). 
was chimeric, consisting of two different $16 \mathrm{~S}$ rDNA fragments, and it was used for further analysis after deleting the part of the $3^{\prime}$-end which did not match in the alignment.

\section{DISCUSSION}

Cultivable bacteria represent only a small proportion of natural microbial communities. Therefore, we have chosen the comparative sequence analysis of rRNA to analyse cultivable and uncultivable bacteria from activated sludge. Although this strategy has been successfully applied to characterize other microbial habitats, it should be stressed that this molecular genetic approach is not completely unbiased. Several points have to be considered for correct interpretation of the data. Assuming that all the bacteria present in an activated-sludge sample were uniformly disrupted by mechanical treatment to release DNA, and assuming further that this purified DNA from the different bacteria was amplified with the same efficiency, the resulting $16 \mathrm{~S}$ rDNA clone library should represent a cross-section of all of the bacteria present in the activated-sludge sample. By restricting the number of clones analysed to about 3000 , only those bacteria that occur in high numbers in the activated sludge have a good probability of being represented. A further source of error is the possible loss of amplified 16S rDNA fragments of bacteria that possess $16 \mathrm{~S} \mathrm{rRNA}$ genes containing internal restriction sites which may be digested prior to the cloning reaction. We attempted to circumvent this problem by using restriction enzymes Bam HI and Sall, cleavage sites for which are only rarely found within $16 \mathrm{~S}$ rRNA genes (Weisburg et al., 1991; Liesack \& Stackebrandt, 1992). However, because most of the $16 \mathrm{~S}$ rRNA gene sequences isolated from the activated sludge were novel, possible cleavage of other PCR products cannot be excluded. Furthermore, it has been shown that the use of different cloning protocols can affect the composition of the resulting clone library (E. Stackebrandt, personal communication), producing altered distributions in the library of $16 \mathrm{~S} \mathrm{rDNA}$ sequences derived from different community members.

PCR artifacts such as the formation of hybrid molecules (chimeric sequences) can occur when amplifying genomic DNA from mixed cultures. This is especially true when low- $M_{\mathrm{r}}$ genomic DNA is used for cloning. The use of a bead-beater in genomic DNA preparation increases the probability of chimeric gene artifacts simply because DNA fragments resulting from this type of extraction are very small. The resulting chimeras may lead to an erroneous interpretation by describing sequences of organisms that do not actually exist in the sample investigated (Liesack et al., 1991). Therefore, a critical analysis of the sequences using e.g. the program CHECKChImera (Olsen et al., 1992), is necessary.

The finding that none of the partial $16 \mathrm{~S}$ rDNA sequences from the randomly chosen recombinants of the $16 \mathrm{~S}$ rDNA clone library was identical to any from the EMBL or GenBank databases suggests that only a few of the bacterial species in the activated sludge complex have been described by classical bacteriological methodologies (Wayne et al., 1987; Olsen, 1990; Ward et al., 1990).

It should be noted that our analysis of the activatedsludge community was not intended to be comprehensive. The comparative sequence analysis of randomly selected recombinants from our $16 \mathrm{~S}$ rDNA clone library represented only a small sample of the diverse micro-organisms present in the activated-sludge sample, but agreed with reports from other groups using $16 \mathrm{~S}$ rRNA analysis to investigate complex microbial communities (Ward et al., 1990; Schmidt et al., 1991; Liesack \& Stackebrandt, 1992).

It might be argued that complete $16 \mathrm{~S}$ rRNA sequences would be necessary for a thorough analysis of the phylogeny of the species from which the cloned $16 \mathrm{~S}$ rRNA gene fragments originated. However, it has been found that comparison of partial sequences is sufficient for an approximate phylogenetic assignment (Lane et al., 1985; Schmidt et al., 1991; Ward et al., 1990; Choi et al., 1994; Hillis et al., 1994).

An indication of the biases of different methods was shown when the results of culture and molecular genetic analysis were compared. With the exception of one sequence (SMKN1), probe MNP1 detected only sequences of nocardioform actinomycetes and mycobacteria in the clone library from the activated-sludge sample, confirming the results of the database search. The finding that only $27 / 3000$ recombinant clones were detected by this probe indicated that these sequences were not representative of the predominant flora in the activated-sludge sample tested. The comparison of the clone sequences with those from the cultured isolates revealed only one identical sequence, namely SMKN35 (cf. isolate M49). This may lead to the assumption that the cultured isolates represented only a small fraction of the organisms present in the activated sludge, obviously selected by the culture conditions.

Inconsistencies in the identification of the cultured isolates by $16 \mathrm{~S}$ rDNA sequence analysis and gas chromatography probably reflect the bias associated with these methods, which is mainly due to the limited size of the databases used for identification. Better results and greater agreement would be achieved by expanding the databases.

The results reported in this paper from comparative sequence analysis suggest that most of the $16 \mathrm{~S} \mathrm{rDNA}$ sequences derived from nocardioform actinomycetes and mycobacteria in the activated sludge represent unknown and as yet uncultivated organisms. The identification, phylogenetic classification and successful cultivation of these nocardioforms is a prerequisite for the elucidation of their physiological role in activated sludge and determination of their true taxonomic position.

\section{Concluding remarks}

The observation that wastewater treatment plants with EBPR are especially susceptible to the development of scum (Wanner \& Grau, 1989) correlates with the increased number of nocardioform actinomycetes and other 
high-G $+C$ Gram-positive bacteria in sewage treatment plants of this type. This observation and the fact that these micro-organisms contain polyphosphate inclusions indicate that they may play a greater role in biological phosphate removal than anticipated (Wagner et al., 1994).

Fluorescently labelled rRNA probes have been applied successfully for the monitoring of bacterial populations in activated sludge as demonstrated by Wagner et al. (1994). The use of a whole set of specific oligonucleotide probes derived from the $16 \mathrm{~S}$ rRNA sequences reported here would be of great help in the identification and enumeration of the organisms directly in sludge samples. With better knowledge of the taxonomic position of relevant nocardioforms in activated sludge, it should be possible to draw conclusions about their growth and nutritional requirements (Wanner \& Grau, 1989). Rapid identification procedures and detailed knowledge of nutrition requirements will be important in controlling growth of these micro-organisms and in preventing the danger of scum formation in activated-sludge plants.

\section{ACKNOWLEDGEMENTS}

We would like to thank A. Wittmer for characterizing culture isolates from activated sludge by gas chromatography with the MIS-system, and S. Rensing for support with the application of the TREecon software. The support of Dr Y. Van de Peer for providing the TREECON software package and an alignment of $16 \mathrm{~S}$ rRNA sequences is gratefully acknowledged. This work was supported in part by a grant from the state of BadenWürttemberg (LGFG).

\section{REFERENCES}

Amann, R., Krumholz, L. \& Stahl, D. A. (1990). Fluorescentoligonucleotide probing of whole cells for determinative, phylogenetic and environmental studies in microbiology. $J$ Bacteriol 172, $762-770$.

Amann, R., Springer, N., Ludwig, W. \& Schleifer, K. H. (1991). Identification in situ and phylogeny of uncultured bacterial endosymbionts. Nature 351, 161-164.

Atlas, R. M. (1983). Use of microbial diversity measurements to assess environmental stress. In Current Perspectives in Microbial Ecology, pp. 540-545. Edited by M. J. Klug \& C. A. Reddy. Washington, DC: American Society for Microbiology.

Blackall, L. L., Harbers, A. E., Greenfield, P. F. \& Hayward, A. C. (1988). Actinomycete scum problems in Australian activated sludge plants. Water Sci Technol 20, 23-29.

Brosius, J., Palmer, L., Kennedy, J. P. \& Noller, H. F. (1978). Complete nucleotide sequence of a $16 \mathrm{~S}$ ribosomal RNA gene from Escherichia coli. Proc Natl Acad Sci US A 75, 4801-4805.

Choi, B. K., Paster, B. J., Dewhirst, F. E. \& Göbel, U. B. (1994). Diversity of cultivable and uncultivable oral spirochetes from a patient with severe destructive periodontitis. Infect Immun 62, 1889-1895.

DeLong, E. F., Wickham, G. S. \& Pace, N. R. (1989). Phylogenetic stains: ribosomal RNA-based probes for the identification of single cells. Science 243, 1360-1363.

Ferguson, R. L., Buckley, E. N. \& Palumbo, A. V. (1984). Response of marine bacterioplankton to differential centrifugation and confinement. Appl Environ Microbiol 47, 49-55.

Fox, G. E., Wisotzkey, J. D. \& Jurtshuk, P., Jr. (1992). How close is close: 16S rRNA sequence identity may not be sufficient to guarantee species identity. Int J Syst Bacteriol 42, 166-170.

Fuhrmann, J. A., McCallum, K. \& Davis, A. A. (1992). Novel major archaebacterial group from marine plankton. Nature 356, 148-149.

Giovannoni, S. J., DeLong, E. F., Olsen, G. J. \& Pace, N. R. (1988). Phylogenetic group-specific oligonucleotide probes for the identification of single microbial cells. $J$ Bacteriol 170, 720-726.

Giovannoni, S. J., Britschgi, T. B., Moyer, C. L. \& Field, K. G. (1990). Genetic diversity in Sargasso Sea bacterioplankton. Nature $345,60-63$.

Göbel, U. B., Geiser, A. \& Stanbridge, E. J. (1987). Oligonucleotide probes complementary to variable regions of ribosomal RNA discriminate between Mycoplasma species. J Gen Microbiol 133, 1969-1974.

Hahn, D., Amann, R. I., Ludwig, W., Akkermans, A. D. L. \& Schleifer, K.-H. (1992). Detection of micro-organisms in soil after in situ hybridization with rRNA-targeted, fluorescently labelled oligonucleotides. J Gen Microbiol 138, 879-887.

Hillis, D. M., Huelsenbeck, J. P. \& Swofford, D. L. (1994). Hobgoblin of phylogenetics? Nature 369, 363-364.

Hoppe, H.-G. (1978). Relationships between active bacteria and heterotrophic potential in the sea. Neth J Sea Res 12, 78-98.

Jones, J. G. (1977). The effect of environmental factors on estimated viable and total populations of planktonic bacteria in lakes and experimental enclosures. Freshwater Biol 7, 61-97.

Jukes, T. H. \& Cantor, C. R. (1969). Evolution of protein molecules. In Mammalian Protein Metabolism, pp. 21-132. Edited by H. N. Munro. New York: Academic Press.

Lane, D. J., Pace, B., Olsen, G. J., Stahl, D. A., Sogin, M. L. \& Pace, N. R. (1985). Rapid determination of $16 \mathrm{~S}$ ribosomal RNA sequences for phylogenetic analysis. Proc Natl Acad Sci US A 82, 6955-6959.

Lasker, B. A., Brown, J. M. \& McNeil, M. M. (1992). Identification and epidemiological typing of clinical and environmental isolates of the genus Rhodococcus with use of a digoxigenin-labeled rDNA gene probe. Clin Infect Dis 15, 223-233.

Lechevalier, H. A. (1989). Nocardioform actinomycetes. In Bergey's Manual of Systematic Bacteriology, vol. 4, pp. 2348-2404. Edited by S. T. Williams, M. E. Sharpe \& J. G. Holt. Baltimore: Williams \& Wilkins.

Lemmer, H. \& Kroppenstedt, R. M. (1984). Chemotaxonomy and physiology of some actinomycetes isolated from scumming activated sludge. Syst Appl Microbiol 5, 124-135.

Liesack, W., Weyland, H. \& Stackebrandt, E. (1991). Potential risks of gene amplification by PCR as determined by $16 \mathrm{~S} \mathrm{rDNA}$ analysis of a mixed-culture of strict barophilic bacteria. Microb Ecol 21, 191-198.

Liesack, W. \& Stackebrandt, E. (1992). Occurrence of novel groups of the domain bacteria as revealed by analysis of genetic material isolated from an Australian terrestrial environment. $J$ Bacteriol 174, 5072-5078.

Miller, L. T. (1982). A single derivatization method for bacterial fatty acid methyl esters including hydroxy acids. J Clin Microbiol 16, 337-347.

Olsen, G. J. (1990). Variation among the masses. Nature 345, 20.

Olsen, G. J., Lane, D. J., Giovannoni, S. J., Pace, N. R. \& Stahl, D. A. (1986). Microbial ecology and evolution: a ribosomal RNA approach. Annu Rev Microbiol 40, 337-365.

Olsen, G. J., Overbeek, R., Larsen, N., Marsh, T. L., McCaughey, M. J., Maciukenas, M. A., Kuan, W.-M., Make, T. J., Xing, Y. \& Woese, C. R. (1992). The ribosomal database project. Nucleic Acids Res 20, 2199-2200. 
Pace, N. R., Stahl, D. A., Lane, D. J. \& Olsen, G. J. (1986). The analysis of natural microbial populations by ribosomal RNA sequences. Adv Microb Ecol 9, 1-55.

Pickup, R. W. (1991). Development of molecular methods for the detection of specific bacteria in the environment. $J$ Gen Microbiol 137, 1009-1019.

Saitou, N. \& Nei, M. (1987). The neighbor-joining method: a new method for reconstruction phylogenetic trees. Mol Biol Evol 4, 406-425.

Sambrook, J., Fritsch, E. F. \& Maniatis, T. (1989). Molecular Cloning: a Laboratory Manual. Cold Spring Harbor, NY: Cold Spring Harbor Laboratory.

Schmidt, T. M., DeLong, E. F. \& Pace, N. R. (1991). Analysis of a marine picoplankton community by $16 \mathrm{~S}$ rRNA gene cloning and sequencing. J Bacteriol 173, 4371-4378.

Sezgin, M., Lechevalier, M. P. \& Karr, P. R. (1988). Isolation and identification of actinomycetes present in activated sludge scum. Water Sci Technol 20, 257-263.

Spring, S., Amann, R., Ludwig, W., Schleifer, K. H. \& Petersen, N. (1992). Phylogenetic diversity and identification of nonculturable magnetotactic bacteria. Syst Appl Microbiol 15, 116-122.

Van de Peer, Y. \& De Wachter, R. (1993). TREECON: a software package for the construction and drawing of evolutionary trees. Comput Appl Biosci 9, 177-182.

Wagner, M., Erhart, R., Manz, W., Amann, R., Wedi, D. \& Schleifer, K. H. (1994). In situ monitoring of the genus Acinetobacter in activated sludge. Appl Environ Microbiol 60, 792-800.
Wanner, J. \& Grau, P. (1989). Identification of filamentous microorganisms from activated sludge: a compromise between wishes, needs and possibilities. Water Res 23, 883-891.

Ward, D. M., Weller, R. \& Bateson, M. M. (1990). 16S rRNA sequences reveal numerous uncultured microorganisms in a natural community. Nature 345, 63-65.

Wayne, L. G., Brenner, D. J., Colwell, R. R., Grimont, P. A. D., Kandler, O., Krichevsky, M. I., Moore, L. H., Moore, W. E. C., Murray, R. G. E., Stackebrandt, E., Starr, M. P. \& Truper, H. G. (1987). Report of the ad hoc committee on reconciliation of approaches to bacterial systematics. Int J Syst Bacteriol 37, 463-464.

Weisburg, W. G., Barns, S. M., Pelletier, D. A. \& Lane, D. J. (1991). 16S ribosomal DNA amplification for phylogenetic study. $J$ Bacteriol 173, 697-703.

Weller, R. \& Ward, D. M. (1989). Selective recovery of $16 S$ rRNA sequences from natural microbial communities in the form of cDNA. Appl Environ Microbiol 55, 1818-1822.

Winker, S. \& Woese, C. R. (1991). A definition of the domains Archaea, Bacteria and Eucarya in terms of small subunit ribosomal RNA characteristics. Syst Appl Microbiol 14, 305-310.

Woese, C. R., Stackebrandt, E., Macke, T. J. \& Fox, G. E. (1985). A phylogenetic definition of the major eubacterial taxa. Syst Appl Microbiol 6, 143-151.

Woese, C. R. (1987). Bacterial evolution. Microbiol Rev 51, 221-271.

Received 14 April 1994; revised 29 August 1994; accepted 21 September 1994. 